\title{
The Persistence of Aboriginal Land Use: Fish and Wildlife Harvest Areas in the Hudson and James Bay Lowland, Ontario
}

\author{
F. BERKES,${ }^{1}$ A. HUGHES,${ }^{2}$ P.J. GEORGE,${ }^{3}$ R.J. PRESTON,${ }^{4}$ B.D. CUMMINS ${ }^{4}$ and J. TURNER ${ }^{5}$
}

\author{
(Received 17 August 1994; accepted in revised form 5 December 1994)
}

\begin{abstract}
The question of the extent and importance of contemporary aboriginal land use in the Canadian North remains controversial, despite more than 20 studies undertaken since the mid-1970s to document Native land claims and to assess impacts of development projects. In planning a community and regional development strategy that takes into account traditional land use and economy, methodologies were developed for a computer-based, integrated land use and wildlife harvest study that could be applied over large geographic areas. Wildlife harvesting areas used in 1990 by the aboriginal people of the Mushkegowuk region, Hudson and James Bay Lowland, were documented by interviewing 925 hunters from eight communities (Moose Factory, Moosonee, New Post, Fort Albany, Kashechewan, Attawapiskat, Peawanuck and Fort Severn). Results show that geographically extensive land use for hunting and fishing persists in the Mushkegowuk region, some $250000 \mathrm{~km}^{2}$. However, the activity pattern of Omushkego (West Main) Cree harvesters has changed much over the decades; contemporary harvesting involves numerous short trips of a few days' duration instead of the traditional long trips. Although the First Nations control only $900 \mathrm{~km}^{2}(0.36 \%$ of the region) as Indian reserve land, they continue to use large parts of their traditional territory.
\end{abstract}

Key words: land use, aboriginal territories, Hudson Bay and James Bay Lowland, Canadian subarctic, Cree, subsistence, wildlife, fisheries

RÉSUMÉ. La question du niveau et de l'importance de l'utilisation actuelle des terres aborigènes dans le Nord canadien demeure controversée, malgré plus de 20 études entreprises depuis le milieu des années 70 afin de documenter les revendications territoriales des autochtones et d'évaluer l'impact des projets de développement. Dans le but de planifier une stratégie de développement communautaire et régional qui tienne compte de l'utilisation des terres et de l'économie traditionnelles, on a mis au point des méthodologies pour une étude intégrée de l'utilisation des terres et du prélèvement faunique, en se servant d'ordinateurs, méthodologies qui pourraient être appliquées à de vastes régions géographiques. On a documenté les zones de prélèvement faunique utilisées en 1990 par les peuples autochtones de la région de Mushkegowuk, basse-terre de la baie d'Hudson et de la baie James, en interviewant 925 chasseurs de huit communautés (Moose Factory, Moosonee, New Post, Fort Albany, Kashechewan, Attawapiskat, Peawanuck et Fort Severn). Les résultats montrent qu'une utilisation intensive, du point de vue géographique, pour la chasse et la pêche persiste dans la région de Mushkegowuk, soit quelque $250000 \mathrm{~km}^{2}$. Cependant, le type d'activité de prélèvement des Cree Omushkego (West Main) a beaucoup changé au cours des ans; les prélèvements contemporains sont réalisés lors de nombreuses expéditions de quelques jours seulement, plutôt que lors de longues expéditions traditionnelles. Bien que les Premières Nations ne contrôlent que $900 \mathrm{~km}^{2}(0,36 \mathrm{p}$. cent de la région) en tant que terres de réserve indienne, elles continuent d'utiliser une grande superficie du territoire traditionnel.

Mots clés: utilisation des terres, territoires autochtones, basse-terre de la baie d'Hudson et de la baie James, subarctique canadien, Cree, subsistance, faune, pêcheries

Traduit pour la revue Arctic par Nésida Loyer.

\section{INTRODUCTION}

The extent and persistence of aboriginal land use in the Canadian North have been recognized only relatively recently. Starting in the 1970s, studies in various parts of the North have built up over the years the composite image of a land under extensive use by a relatively small number of hunters operating out of widely scattered, remote communities. Persistence of land use parallels the persistence of a land-based economy in the northern parts of Canadian provinces and in the northern territories (Fast and Berkes, 1994). This land-based economy has remained a cornerstone of the mixed economies of many

\footnotetext{
${ }^{1}$ Natural Resources Institute, University of Manitoba, Winnipeg, Manitoba R3T 2N2, Canada

${ }^{2}$ Department of Geography, Brock University, St. Catharines, Ontario L2S 3A1, Canada

${ }^{3}$ Department of Economics, McMaster University, Hamilton, Ontario L8S 4M4, Canada

${ }^{4}$ Department of Anthropology, McMaster University, Hamilton, Ontario L8S 4M4, Canada

${ }^{5}$ Mushkegowuk Council, P.O. Box 370, Moose Factory, Ontario P0L 1W0, Canada

(C) The Arctic Institute of North America
} 
northern communities, and despite the predictions of economic planners to the contrary, it has not been replaced by the modern wage economy (George and Preston, 1987; Berkes et al., 1994).

Land use studies in the Canadian North have been undertaken since the 1970s largely for two purposes: to document Native land claims, and to assess environmental impacts of development projects. The pioneering project which provided inspiration and methodology for many of these studies was The Inuit Land Use and Occupancy Project (Freeman, 1976), in which northern experts and southern researchers collaborated to document Native land use over a wide area from an aboriginal perspective.

There has never been a full inventory of aboriginal land use studies in Canada, partly because many are in the form of reports which are not readily available, and others, such as those used in court cases, are not public. Weinstein (1993) provided a preliminary compilation of 20 aboriginal land use studies across Canada. His list, limited to studies initiated by aboriginal organizations, documented that these agencies have been actively researching aboriginal land use in an effort to defend the resource base from the incursions of outsiders (M. Weinstein, pers. comm., 1994). Fast and Berkes (1994) listed 16 land use studies from the Hudson Bay bioregion alone, which was double the number in Weinstein's (1993) selective inventory for that region. Had they considered unpublished studies by Manitoba Keewatinowi Okimakanak and other aboriginal agencies, the number would have been larger still (M. Anderson, pers. comm., 1994).

The initial focus of land use studies was the Inuit, and land use mapping as a discipline in Canada initially developed around the Inuit. Since the path-breaking work of Freeman (1976) and Brice-Bennett (1977), related in both cases to land claims, innovative mapping has continued with the Nunavut Atlas (Riewe, 1992). Prepared for the Tungavik Federation of Nunavut, the atlas is a comprehensive series of land use maps that played a critical role in land selection by the Inuit and thus in the creation of Nunavut. To the south of the Inuit areas, many aboriginal land use studies have been undertaken for both impact assessment and land claims. One of the most detailed of these was done by Weinstein (1976) to document the extent of land use by the Cree of Chisasibi (formerly Fort George), and the potential impacts of the James Bay I hydroelectric development project on their wildlife harvests. Several other studies have also addressed impacts, including that by Hrenchuk (1993) in the South Indian Lake area affected by the ChurchillNelson hydroelectric development project in Manitoba.

Many aboriginal land use studies go beyond the merely utilitarian function of documenting native occupancy of land or the impact of development (Abel and Friesen, 1991; Feit, 1991; Asch and Tychon, 1993; Andrews, 1994). They also document the meaning of land and "homeland" for groups of aboriginal people, and thus contribute to the cross-cultural understanding of aboriginal cultures by Euro-Canadian society. British Columbia has been the setting for many aboriginal mapping projects related to land claims, development impacts, and resource planning and allocation. Some insights derived from these maps have been proving useful for other societal needs. Mapping in the Gitksan and Wet'suwet'en area, for example, has been used as a sophisticated example of bioregional planning towards the "building of new, ecologically sustainable cultures and communities" with a sense of place (Aberley, 1993:iii).

Land use maps can serve to convey aspects of aboriginal cultures and traditional ecological knowledge. For example, Brody's (1981) work has shown the feasibility of achieving cross-cultural insights by using maps as a focus of contact. Culture consists of a storehouse of knowledge that guides a people's relationships and activities within their environment. This knowledge is guided by a worldview or a mental "map" of relationships of a people to places, people, and animals (Brody, 1981; Ridington, 1988; Hallowell, 1992). "Places" are very important for cultural identity, as in the Inuit names formed from place of origin and the suffix -miut (the people of). Most, if not all, aboriginal groups and subgroups define their identity, as the Inuit do, in terms of the places in which they hunt, gather, live, and travel through the annual cycle.

The major practical significance of land use studies is in the area of self-government. Many northern native groups regard the question of land control as crucial to self-governance. Although the legal issue of aboriginal claims is beyond the scope of the present paper, self-government as a mechanism for sustainable land and resource use is relevant. Continued participation in land-based activities is important for social well-being (Niezen, 1993) and thus for social as well as ecological and economic sustainability of James Bay area peoples (Berkes et al., 1994). Groups which are dependent on the land have more incentives for the sustainable use of that land and its resources than outsiders (Usher, 1987; Berkes, 1989).

This paper reports findings of a land use study carried out jointly by the Research Program for Technology Assessment in Subarctic Ontario (TASO), the Mushkegowuk Council, its constituent First Nations, and the Omushkegowuk Harvesters Association. The overall purpose of the project was to help the regional Council and its associations develop a strategy for natural resource co-management, self-government, and sustainable regional development.

The objectives of this paper are to report on the location of "places"- the geographical distribution of fish and wildlife harvests over a one-year cycle in the study area. Specifically, the study seeks to determine a) the distribution of major harvesting activities, b) harvest areas by season, c) the use of harvest areas by community, and d) the overall extent of the area used for hunting and fishing, and to explore the significance and policy implications of these findings.

Land use studies are of special interest to the Cree partners of the project for the assessment of social and environmental impacts of potential hydroelectric projects in the Moose River Basin and of other developments in the region, for selfgovernance, and for strengthening land use and hunting tradition in the communities. The context of the overall project is fully described elsewhere (George and Preston, 1987, 1992; George, 1989); experience with co-management may be found in Berkes et al. (1991); the history and traditional economy of 
the Moose River Basin portion of the study area is discussed in George et al. (in press); and the quantitative importance of hunting and fishing activity and its economic value for the Mushkegowuk region are described in Berkes et al. (1994). A technical report contains the questionnaire (Berkes et al., 1992); another provides additional distribution maps of the geography of harvest and further details of methodology (Hughes et al., 1993).

\section{THE STUDY AREA}

The Mushkegowuk region roughly coincides with the Hudson and James Bay Lowland, which is the largest wetland region of Canada. The region extends from the Quebec border along the coast of James Bay and Hudson Bay to the Manitoba border. It is boreal and subarctic, with a fringe of tundra along the Hudson Bay coast. There is some forestry in the southern part, some mining, very little agricultural land, and limited hydroelectric potential because of the flatness of the terrain (OMNR, 1985). The region is both a productive wildlife area, especially for waterfowl (Prevett et al. 1983; OMNR, 1985), and an important hunting and fishing area for the local people (OMNR, 1985; Thompson and Hutchison, 1989).

The Omushkego Cree (also called the West Main Cree or Swampy Cree) are the people of the Western James Bay and Hudson Bay Lowland. Historically, they occupied the muskeg (from the Cree word for wetland), and ranged 200-300 km inland from the coast (Honigmann, 1981). The Omushkego Cree make up the bulk of the resident regional population. The aboriginal population also includes the descendants of the Eastern James Bay Cree (the Mocreebec First Nation), living mainly in Moose Factory; Metis, some of whom have Indian status, also living mainly in Moose Factory; and some OjiCree people, mainly in Fort Severn. The resident Native population of the region was about 6500 in 1990, according to band council records. The two major settlements are Moose Factory, historically a major fur trading post, and Moosonee. The largest concentration of non-Native people in the region lives in Moosonee. Cree is the major language used at home in the region, but English is used to a greater extent in Moosonee and Moose Factory.

Traditionally, the aboriginal people of the region lived in scattered local bands, moving with the seasons and subsisting on fish and game (Honigmann, 1981; Flannery and Chambers, 1986; George and Preston, 1987). The locus of "home" gradually changed from a cluster of places in the bush to village settlement (Preston, 1986). The population no longer lives in scattered hunting groups, but is concentrated in Moosonee and eight First Nation communities-Moose Factory, Mocreebec, New Post, Fort Albany, Kashechewan, Attawapiskat, Peawanuck (formerly Winisk) and Fort Severn. Fort Severn is the only one of these that is not a member of the Mushkegowuk Council; it was included in the study because it is a member of the Omushkegowuk Harvesters Association, shares the Lowland region, and utilizes much the same wildlife populations.

\section{STUDY METHODS}

Most aboriginal land use studies employ one of two general methodologies. The first, introduced by Freeman (1976), documents land use in living memory by producing map biographies of active resource users and elders. These biographies, marked directly on maps and annotated, summarize each respondent's recollections of activities on the land, such as hunting, fishing and gathering, as well as travel areas, camping locations, and burial and other culturally important sites. Composite maps are then created from individual biographies to summarize collective land use.

The second methodology combines wildlife harvesting studies and the mapping of actual harvest sites (Weinstein, 1976). Harvest locations of individual hunters are coded, usually over a one-year cycle (as the need for precision and detail makes it difficult to carry out multi-year studies), and composite maps are created by summing up individual harvesting sites according to community, species, or season. The present study uses the second approach as adapted from Weinstein (1976). The questionnaire was adapted from NHR (1982).

Data were collected by administering a detailed questionnaire to "potential hunters" among the resident aboriginal population of the region. Potential hunters are defined as all males 18 years of age and over and female heads of household for households having no adult males. Sampling of First Nations community members was conducted by selecting potential hunters from band lists. Moosonee, which is not a reserve, was sampled by selecting from a list of native households. Since not all potential hunters could be interviewed, the sample was stratified in consultation with local experts. Potential hunters were classified as "intensive," "active," "occasional," or "non-hunter" (for definitions, see Berkes et al., 1994). Respondents were chosen to include more intensive and active hunter's categories; this was important for improving the confidence levels of the harvest portion of the study (Usher and Wenzel, 1987).

The questionnaire was administered orally and the answers recorded by the interviewer, himself a Native from the community in question. To ensure consistency, all of the interviewers were trained by the head of the field study who also accompanied the interviewers (usually two per community) in the administration of several questionnaires. The study included verification of the data by field personnel and community experts. Any unusual or questionable harvest locations were rechecked and corrected as necessary.

The numbers interviewed ranged from 235 for Moose Factory to 13 for New Post, for a total of 716 hunters, representing 52\% of potential hunters, excluding Attawapiskat. Moose Factory data included Mocreebec. For Attawapiskat, Cummins (1992) interviewed 209 out of 275 potential hunters for a $76 \%$ coverage. Including Attawapiskat, 925 hunters were interviewed, for a $56 \%$ coverage overall (Table 1). Hunters in the intensive and active categories accounted for $78 \%$ of the total respondents in five communities; samples in Attawapiskat, Fort Severn and New Post were not stratified. 
TABLE 1. Resident native population ${ }^{1}$ of the study area: number of residents, households, total numbers $(\mathrm{T})$ of "potential hunters"2, and numbers interviewed (I).

\begin{tabular}{lrrrr}
\hline & & & \multicolumn{2}{c}{ Hunters } \\
\cline { 3 - 5 } Communities & Pop & HH & T & I \\
\hline Moose Factory & 1750 & 292 & 444 & 235 \\
Moosonee & 1250 & 208 & 297 & 137 \\
New Post & 72 & 12 & 20 & 13 \\
Fort Albany & 625 & 104 & 173 & 90 \\
Kashechewan & 1000 & 187 & 273 & 168 \\
Attawapiskat & & 220 & 275 & 209 \\
Peawanuck & 1214 & 38 & 70 & 44 \\
Fort Severn & 227 & 55 & 92 & 29 \\
Total & 332 & 1116 & 1644 & 925 \\
\hline \hline
\end{tabular}

${ }^{1}$ Population and household $(\mathrm{HH})$ numbers are based on band records and Indian and Northern Affairs data for 1990 (1989 for Attawapiskat).

2 "Potential hunters" are defined as all males 18 years and over, plus female heads of households.

${ }^{3}$ From Cummins (1992); estimated on the basis of 220 households from which 209 were inventoried by interviewing the household head.

Time periods in the questionnaire were chosen according to Cree hunting seasons. The one-year period commenced in November 1989 (freeze-up and the beginning of the 1989-90 winter season) for the three southern communities of New Post, Moose Factory and Moosonee, and in June 1990 (the beginning of the summer season) for the other communities.

Respondents were asked about the size of their harvest over the one-year cycle (i.e., numbers of animals caught, by species and season), harvest locations, hunting success rates, the number of days of harvesting, and management techniques. The harvests of all individuals living in a house (i.e., female members of the family and males under 18 years) were included in the report of the head of the household. Other males 18 and over reported their own harvests.

When specifying harvest locations, each respondent (except those in Attawapiskat) was shown a National Topographic Series $1 / 250000$ scale map of the area in question and asked to point out the Universal Transverse Mercator (UTM) $10 \mathrm{~km}$ grid square(s) in which he or she had been active. Each square was recorded using a standard alphanumeric code of the form $\mathrm{NH} 21$, in which the letters identify a $100 \times 100 \mathrm{~km}$ square from the UTM grid, and the numbers give the abbreviated rectangular coordinates of the southwest corner of the $10 \times 10 \mathrm{~km}$ square.

The questionnaire data were entered into a relational database using the OS/2 Database Manager, which was then used to derive summary values of various kinds, in particular, counts of the numbers of each species caught, broken down by season and by community. These counts were adjusted, using correction factors based on the proportion of respondents to numbers of potential hunters, to produce projected community totals, and converted into harvest yields.

Maps were produced using a combination of Database Manager, the SPANS geographical information system and the CorelDraw graphics program. All the essential mapping work was done in SPANS, using data generated by Database Manager. The mapped distributions were exported as .DXF files into CorelDraw, which was used to produce final publication-quality output.

Two basic kinds of maps were produced: a) distribution maps, identifying those grid squares in which certain types of activity took place; and b) intensity maps, showing the level of hunter activity in each grid square. Within each group there were further breakdowns by community, species, and season.

In Attawapiskat, the land use study followed a methodology similar to that of Freeman (1976), and the map data were later converted to a form compatible with the rest of the communities. Harvest locations were recorded in the form of polygons drawn on map overlays at a scale of $1 / 1000000$, indicating the harvesting areas of individual hunters over the period 198689. These data were manually converted to grid-square form by preparing a transparent overlay of the relevant part of the UTM grid, superimposing this on each of the map overlays in turn, and cumulatively recording the grid squares in which harvesting activity took place. To make the results as comparable as possible with the data from other communities, only the 1989 data from Attawapiskat were processed.

\section{RESULTS}

\section{Distribution of Major Harvesting Activities}

Not all harvesting activities are equally important. Of the major activities, the spring waterfowl hunt attracted about 14000 person-days of harvesting effort in 1990; the fall waterfowl hunt, fishing (all seasons together), and trapping, each about 10000 person-days, and big game hunting about 7000 person-days (Berkes et al., 1994). Small game harvesting effort was not quantified separately, because small game hunting and snaring were often combined with other subsistence activities. One major harvesting activity, trapping, was quantified but not mapped by itself, as explained in the Discussion section.

The intensity of harvesting (number of days in the bush per year) by harvester and by community is shown in Table 2 . Most of the harvesters spent 10 to 50 days per year in various activities; only $18 \%$ did not report any harvesting activity and $6 \%$ reported more than 100 days per year. Respondents who took part in trapping were asked to state the length of their longest stay in the bush. One-third relied on overnight or weekend trips, and nearly one-third (29\%) stayed in the bush for over one month at a time (Table 3).

Each of the ten maps in Figures 1 to 3 corresponds to one of the major activities in the yearly cycle of Mushkegowuk region hunters, as identified by them. Each symbol in the maps represents a $10 \mathrm{~km}^{2}$ grid from which an actual harvest was recorded. Figure 1 shows the areas used for hunting the two major species of big game, moose (Alces alces) and caribou (Rangifer tarandus). During the fall moose hunt and the winter caribou hunt, hunters distributed themselves relatively evenly 
over a large area. The winter moose hunt was more limited in extent, and the fall caribou hunt even more so.

Fishing areas indicate the location of harvests for nine major species, of which lake whitefish (Coregonus clupeaformis) was the most important. The distribution of fishing activity (Fig. 2) documents the importance of the major rivers and especially the estuary areas. Small game were also mapped as a group. The major species in the harvest was snowshoe hare (Lepus americanus). The catch also included willow ptarmigan (Lagopus lagopus) and three species of grouse. Small game harvesting (Fig. 2), in which women and children are relatively more active, tended to be concentrated around communities.

TABLE 2. Number of harvesters reporting 0 days, 1-10 days, 1125 days, 26-50 days, 51-100 days and over 100 days of harvesting per year $^{1}$

\begin{tabular}{lrrrrrrr}
\hline \hline Communities & 0 Days & $1-10$ & $11-25$ & $26-50$ & $51-100$ & $>100$ & Total \\
\hline Moose Factory & 61 & 57 & 102 & 107 & 80 & 38 & 444 \\
Moosonee & 114 & 42 & 78 & 30 & 27 & 6 & 297 \\
New Post & 0 & 6 & 3 & 2 & 8 & 2 & 20 \\
Fort Albany & 66 & 50 & 37 & 16 & 4 & 0 & 173 \\
Kashechewan & 0 & 19 & 85 & 96 & 56 & 17 & 273 \\
Peawanuck & 8 & 21 & 17 & 14 & 6 & 4 & 70 \\
Fort Severn & 0 & 6 & 10 & 26 & 32 & 19 & 93 \\
Total & 249 & 200 & 332 & 291 & 213 & 86 & 1370 \\
\hline \hline
\end{tabular}

${ }^{1}$ The numbers are projected data, taking into account the stratification and weighting. (Berkes et al., 1994). Row and column totals may not add up exactly due to rounding. Table excludes Attawapiskat data.

TABLE 3. Trappers longest stay in camp ${ }^{1}$

\begin{tabular}{lccc}
\hline \hline Communities & $\begin{array}{c}\text { Overnight/ } \\
\text { Weekend }\end{array}$ & 1-4 Weeks & Over a Month \\
\hline Moose Factory & 14 & 11 & 22 \\
Moosonee & 15 & 10 & 2 \\
New Post & 3 & 1 & 0 \\
Fort Albany & 1 & 1 & 1 \\
Kashechewan & 0 & 21 & 17 \\
Peawanuck & 9 & 4 & 1 \\
Fort Severn & 8 & 10 & 1 \\
Total & 50 & 58 & 44 \\
\hline \hline
\end{tabular}

${ }^{1}$ The table is based only on respondents reporting trapping activity.

Two major waterfowl species were mapped, the lesser snow goose (Anser c. caerulescens), which dominates the fall hunt, and the Canada goose (Branta canadensis), which dominates the spring hunt. Figure 3 shows that in the fall, waterfowl hunters were more concentrated along the coast. In spring, however, geese were hunted along inland waterways as well as on the coast.

Figures 1 to 3 thus account for four major species and two species groups, for a total of 18 species out of the 41 recorded in the harvest survey (Berkes et al., 1994). Some additional species such as black bears (Ursus americanus) were mapped but not shown here because of small numbers. Others such as ducks, which are hunted over a wide area, were not mapped.

\section{Harvest Area by Season}

Figure 4 summarizes harvest areas used by season, winter (freeze-up to break-up), spring (break-up to June), and summer/fall (June to freeze-up). Winter is the main season for caribou hunting, fishing and (not shown in maps) trapping; spring is the main season for waterfowl hunting and fishing; and summer is for fishing only, followed by fall which is for waterfowl hunting, moose hunting, and fishing. Small game hunting is carried out mainly in winter and fall. There is some trapping in late fall, before freeze-up; some moose hunting in winter; and some caribou hunting in fall, especially in the Hudson Bay coastal area.

In summarizing all hunting activity types aggregated by season, Figure 4 indicates that the extent of harvesting activity is comparable in all three seasons. However, spring is a shorter season than the other two, so the harvesting level shown in Figure 4 represents a burst of activity in the annual cycle. The maps also show that patterns of activity are different by season. Hunters from Hudson Bay communities range more extensively in winter. Hunters of Kashechewan and Fort Albany, as well as Attawapiskat (Cummins, 1992), stay close to the coast in spring, but range more extensively in fall and winter. Hunters of the three most southerly communities range almost as extensively in all three seasons, but perhaps somewhat more in the fall.

There are seasonal differences in the harvesting areas by species, as indicated earlier in Figures 1 to 3. Moose and caribou, for example, are reported from different areas in different seasons. Fishing areas are also quite different in the three seasons. These seasonal differences by animal groups mask species-by-species differences, which are too detailed to be reported here. Suffice it to say that of the 41 major species in the harvest (Berkes et al., 1994), each has its time(s) and place(s) for harvesting.

\section{Harvest Area by Community}

Figure 5 shows the harvesting areas (all species, all seasons) reported by community of residence of the hunters interviewed. Each community has a distinct area from which most of the harvesting activity for that community was reported. There are two exceptions. Moosonee and Moose Factory hunters share the same general area, as do Fort Albany and Kashechewan hunters. Moosonee is not a traditional community, and does not have its own community harvesting area. In the case of the adjacent communities of Fort Albany and Kashechewan, these two were differentiated, mainly by religion, only in the last forty years.

There is considerable overlap in community hunting areas of adjacent communities, for example, Moose Factory and New Post. Some of the overlaps represent intermarriage; some represent reciprocal hunting rights of adjacent family groups (often through marriage). Some of the overlaps reflect the fact 

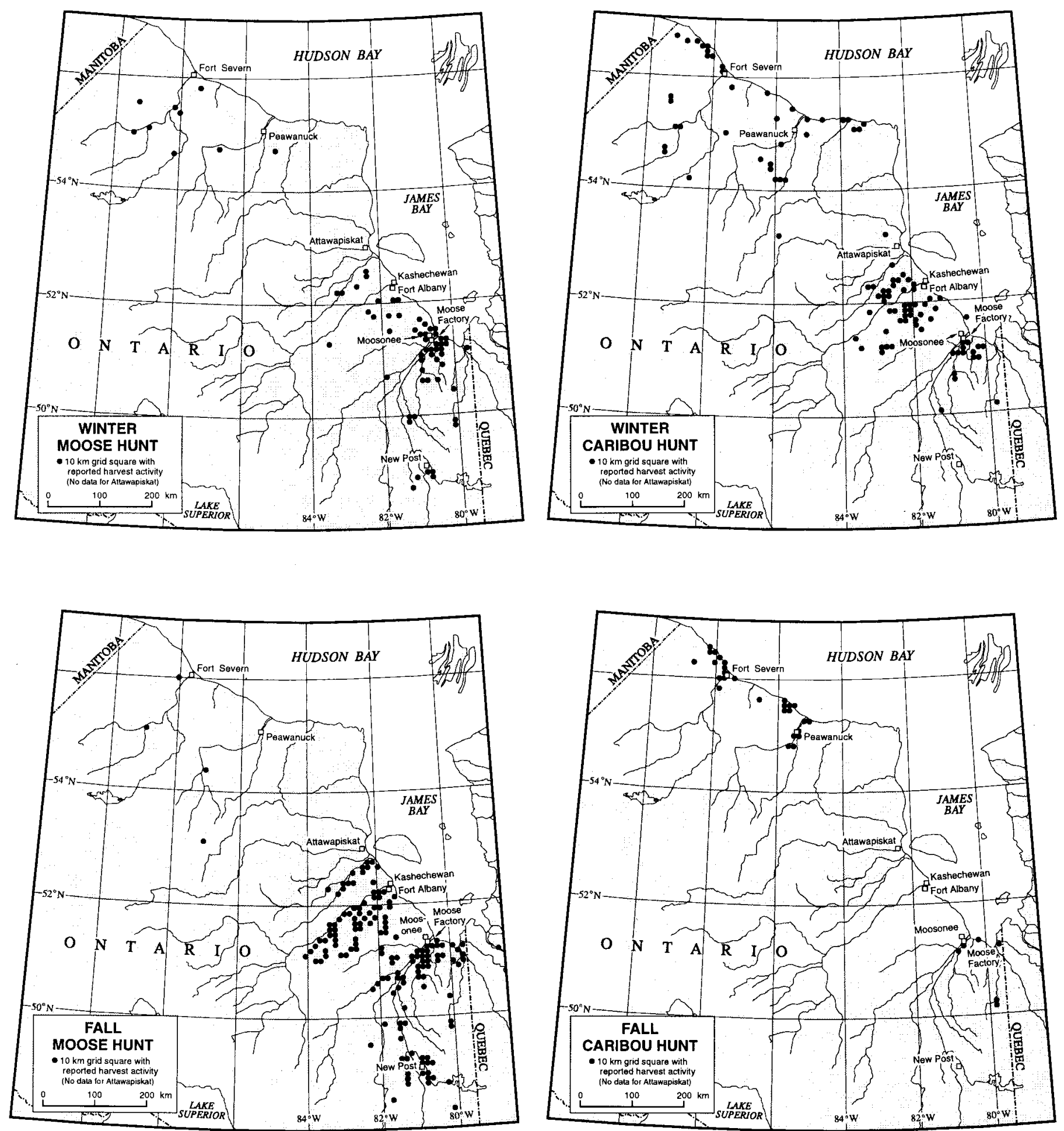

FIG. 1. Harvesting areas used in 1990 for big game animals, by season.

that many extended families reside in more than one settlement; for example, some Attawapiskat families have members in Peawanuck.

Some of the outlying distribution points probably reflect visits by hunters to other communities to join hunting groups there. They need not indicate ongoing traditional land use rights but only short-term arrangements. Omushkegowuk Cree hunters often visit or are invited to the traditional areas of others, as is done elsewhere among many other Algonquian peoples (Feit, 1991). Such reciprocal arrangements may be made both within and across communities. Finally, the relatively large number of outlying points reported by Moosonee hunters reflect the fact that the aboriginal population of Moosonee originally came from a number of different Native communities. 

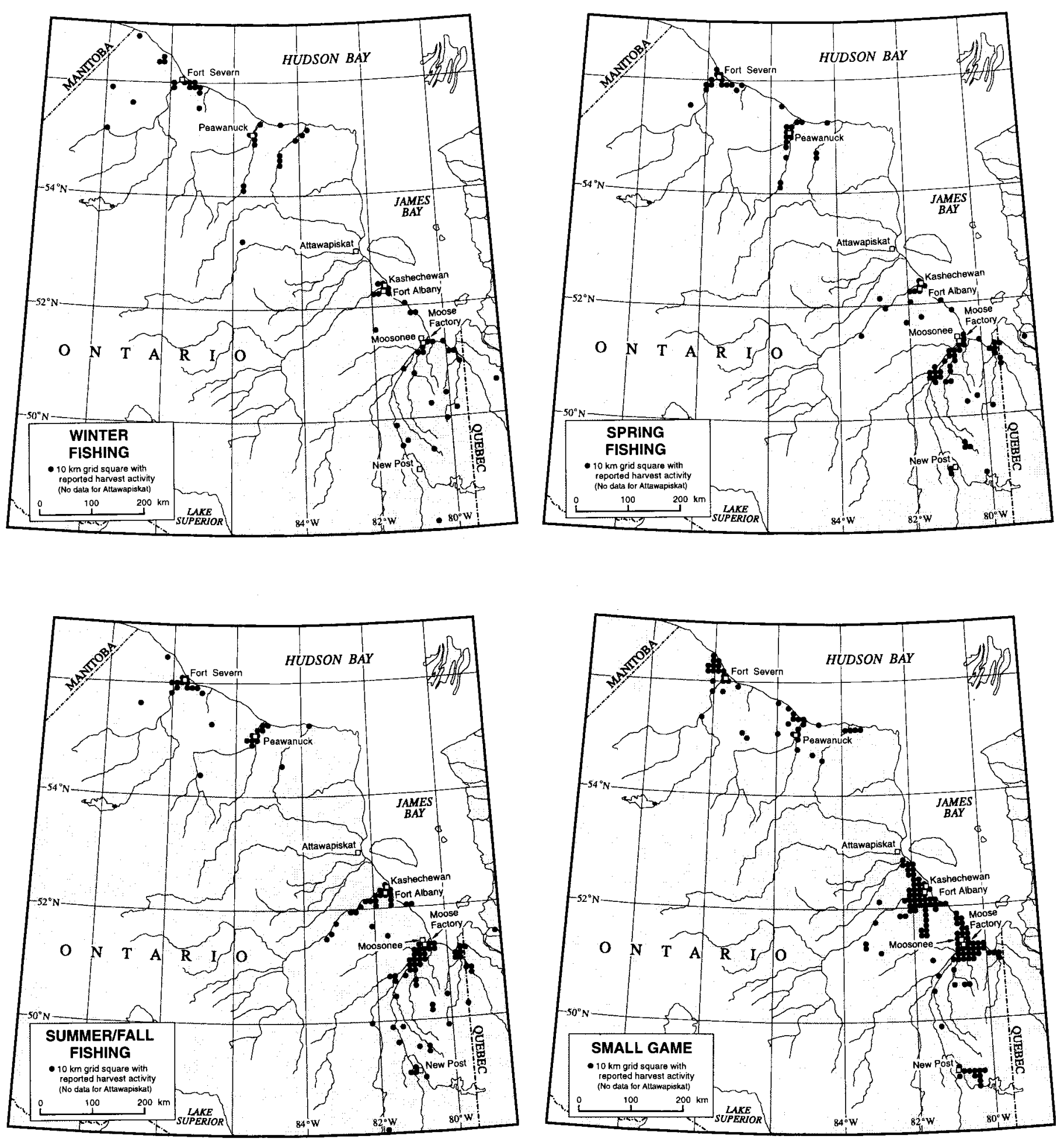

FIG. 2. Harvesting areas used in 1990 for fishing (by season) and small game.

The harvest area for Attawapiskat is large relative to the others. There are several reasons for this, as explained in the Discussion section. As well, the traditional area of Attawapiskat is very large to begin with; it extends far to the north and west.

Finally, Figure 6 is a composite map, including Attawapiskat, which shows the overall extent of the area used for hunting and fishing over one yearly cycle.

\section{DISCUSSION}

\section{Land Use in Historical Context}

Various land use studies in Canada's North have shown that aboriginal peoples have continued using extensive areas for hunting and fishing (e.g., Freeman, 1976; Weinstein, 1976; 

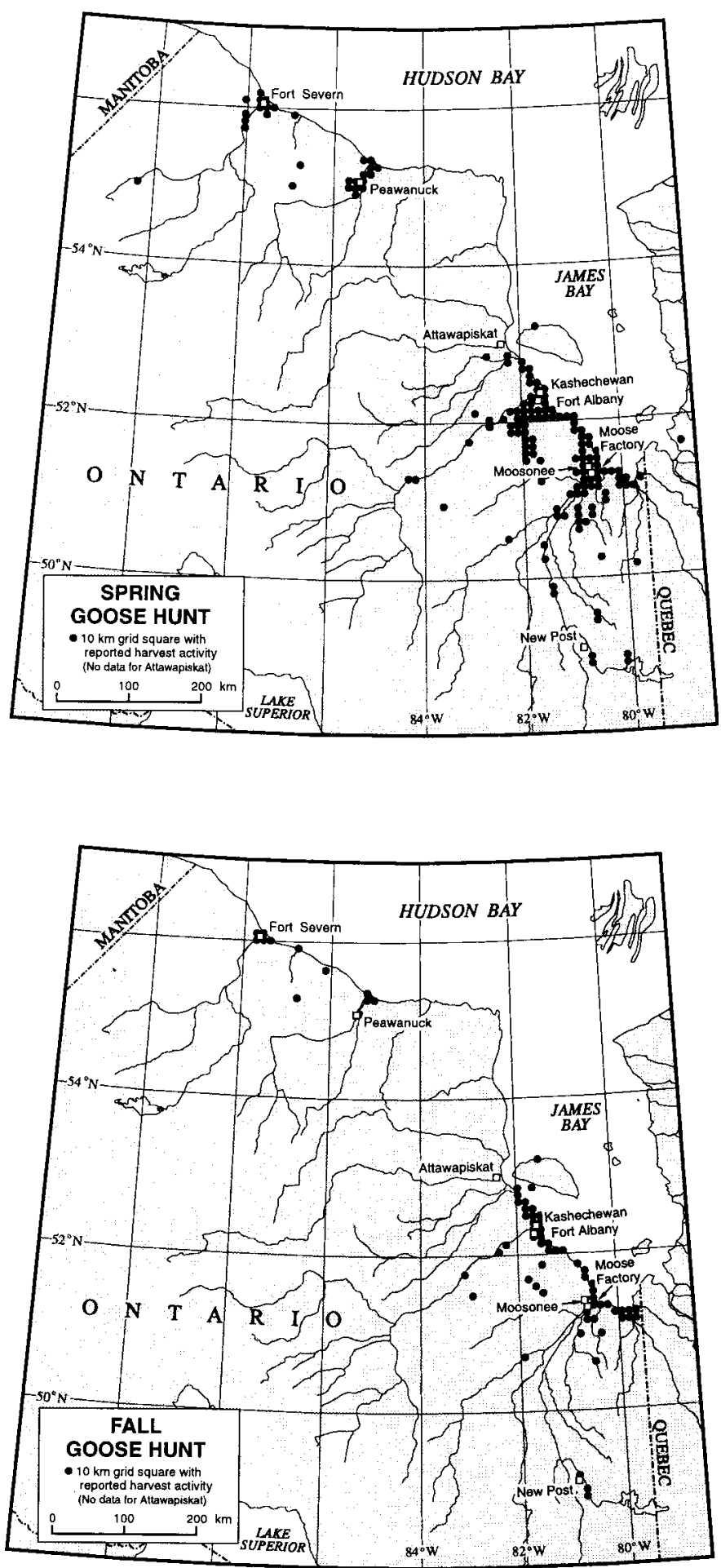

FIG. 3. Harvesting areas used in 1990 for goose hunting, by season.

Riewe, 1992), and the present study strongly supports these findings. The approximate dimensions of the nineteenth century land use area of the West Main Cree or Omushkego people are indicated on Figure 6 with a dashed line (Honigmann, 1981). The harvesting area used by the people of Mushkegowuk region in 1990 shows a good fit with this traditional territory, except for the Manitoba portion of the range and the New Post area.
Historically, the territory extended west to the Nelson River and included the regional centre of York Factory located at the mouth of the river (Honigmann, 1981). When the York Factory trading post and settlement closed down in 1957, the people were relocated to several communities inland, many of them outside the traditional territory of the West Main Cree. Some were settled in Fort Severn and continue to use some of this former York Factory area. The traditional Omushkegowuk territory within Manitoba has also been used in recent years by the people of Shamattawa, Fox Lake and York Landing $(\mathrm{H}$. Fast, pers. comm. 1994).

In the case of New Post, recent land use represents an expansion of the range of the Omushkego Cree. New Post is a relatively new community; in fact, the present site of the reserve dates back only to 1985 . New Post was a small trading post from 1867 to 1925 , and a Native community from the time of Treaty No. 9 in 1905. The post closed down in 1925, and the tiny community almost disappeared in the "frontier days" of the 1920s and the 1930s, as all but two families died out (Schuurman et al., 1992). Most of the current inhabitants of New Post descended from one of these two families.

There have been several other land use studies in Northern Ontario, two of which are historical. Cooper's map of family hunting territories of the James Bay coast, including the Moose Band, dates from the end of the nineteenth century (Flannery and Chambers, 1986). The extent of the land used by the Attawapiskat Band and family hunting territories during 194748 were given in Honigmann (1961). Contemporary land use by the Ojibwa (Nishnabe) of north-central Ontario, including the Fort Severn area, was described by the Kayahna Tribal Area Council (1985). The latter study reported that not only land use patterns but also social organization related to communal and family-based land use were persisting among the Ojibwa.

A detailed harvesting and land use study, covering virtually the same area as the present one, was undertaken by the Ontario Ministry of Natural Resources in 1981-82 (OMNR, 1985; Thompson and Hutchison, 1989). The results of the OMNR study show many similarities to the present one, especially in the areas used for fishing, moose hunting, and goose hunting. Both studies indicate the heavy use of the coast and waterways; the present study shows more use of inland areas than does Thompson and Hutchison (1989). Above-mentioned maps (Honigmann, 1961; Flannery and Chambers, 1986; Thompson and Hutchison, 1989) are all reproduced in the appendix of Hughes et al. (1993).

\section{Limitations of the Study}

The findings reported here need to be qualified on a number of counts. The major limitation of the study is that it is based on only one annual cycle. Thus, it is not a land use study that covers a composite of map biographies, providing activity patterns over a number of years and for a variety of land uses, including travel routes, camp sites, and burial grounds. Rather, it is a one-year snapshot of the geography of wildlife harvesting in the study area. A more detailed study involving map biographies is now underway. 

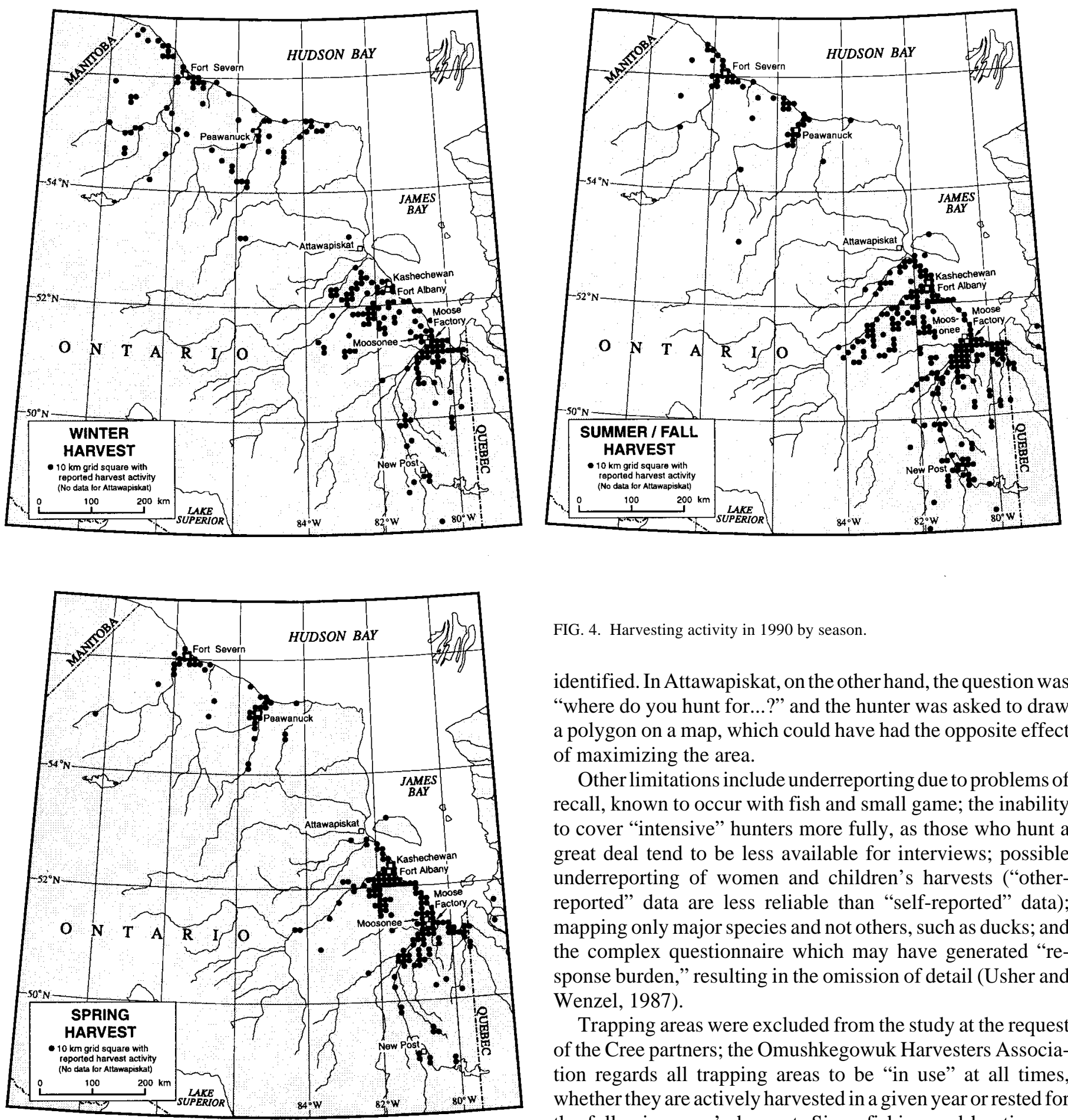

FIG. 4. Harvesting activity in 1990 by season.

identified. In Attawapiskat, on the other hand, the question was "where do you hunt for...?" and the hunter was asked to draw a polygon on a map, which could have had the opposite effect of maximizing the area.

Other limitations include underreporting due to problems of recall, known to occur with fish and small game; the inability to cover "intensive" hunters more fully, as those who hunt a great deal tend to be less available for interviews; possible underreporting of women and children's harvests ("otherreported" data are less reliable than "self-reported" data); mapping only major species and not others, such as ducks; and the complex questionnaire which may have generated "response burden," resulting in the omission of detail (Usher and Wenzel, 1987).

Trapping areas were excluded from the study at the request of the Cree partners; the Omushkegowuk Harvesters Association regards all trapping areas to be "in use" at all times, whether they are actively harvested in a given year or rested for the following year's harvest. Since fishing and hunting are usually carried out at the same times and locations as trapping, the omission of areas used exclusively for trapping makes relatively little difference in the overall land use in most areas. However, in regions in which trapping is a primary activity, large areas covered by trappers would be inadequately represented in harvest maps. This consideration applies mainly to Fort Severn, where marten trapping over extensive areas was being carried out in 1990 .

Finally, the percentage of questionnaire coverage of the hunters reflects the completeness of the mapping data. At the one extreme is Attawapiskat with a 76\% coverage. At the other 

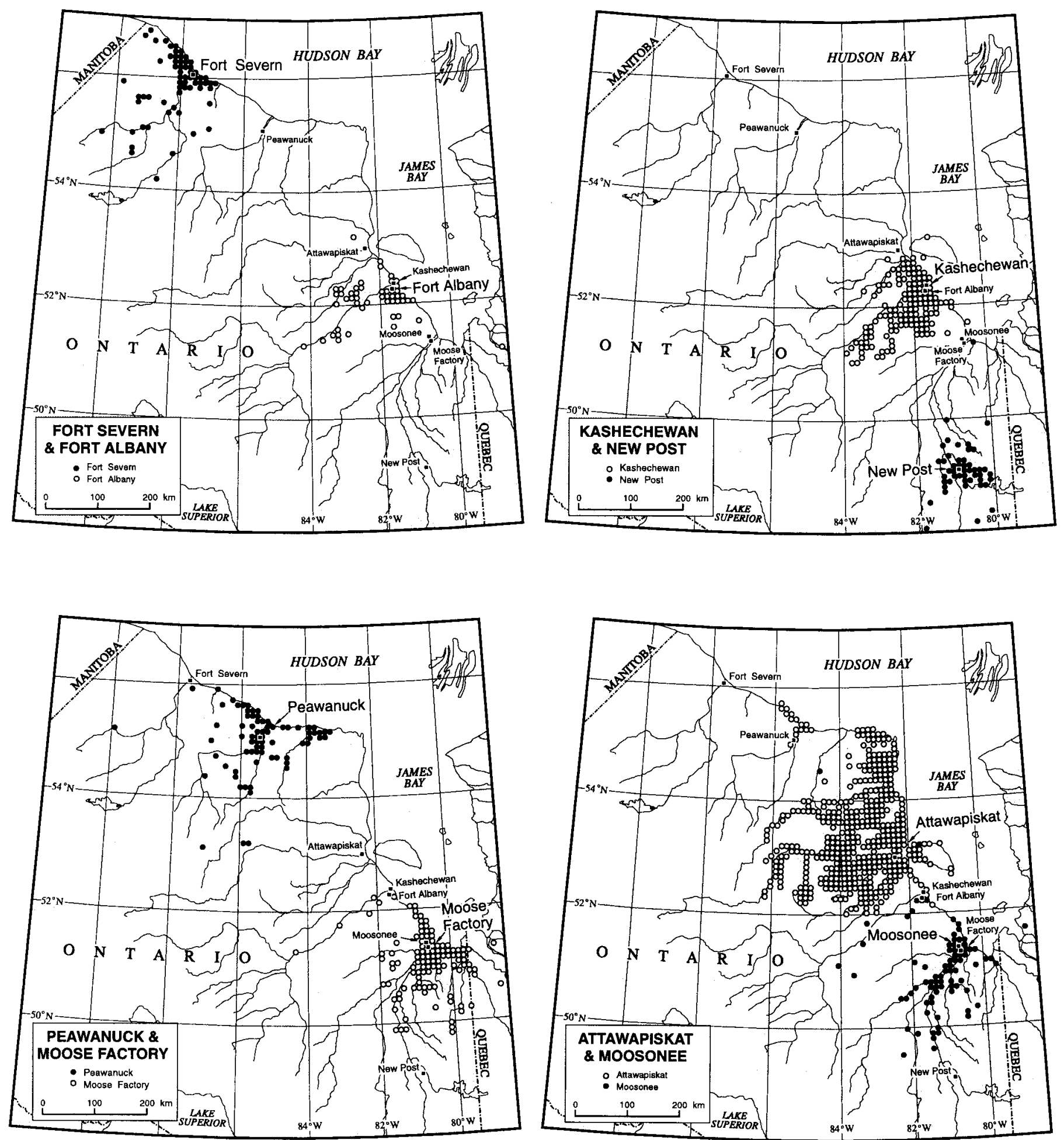

FIG. 5. Distribution of harvest activity in 1990 by community.

are Fort Severn and New Post, where the relatively small, random samples resulted in data which must be considered incomplete. With the above limitations in mind, the data summarized in Figure 6, representing a 56\% coverage of all hunters but a proportionally higher coverage $(78 \%)$ of intensive and active harvesters, perhaps account for two-thirds to three-quarters of the actual overall activity on the land in 1990.

\section{Policy Implications}

The present study shows that the geographic extent of harvesting areas in the Mushkegowuk region may not have changed much over the decades, and there is no evidence that land-based activity diminished between 1981 and 1990. But the lifestyle and activity patterns of harvesters have changed a 


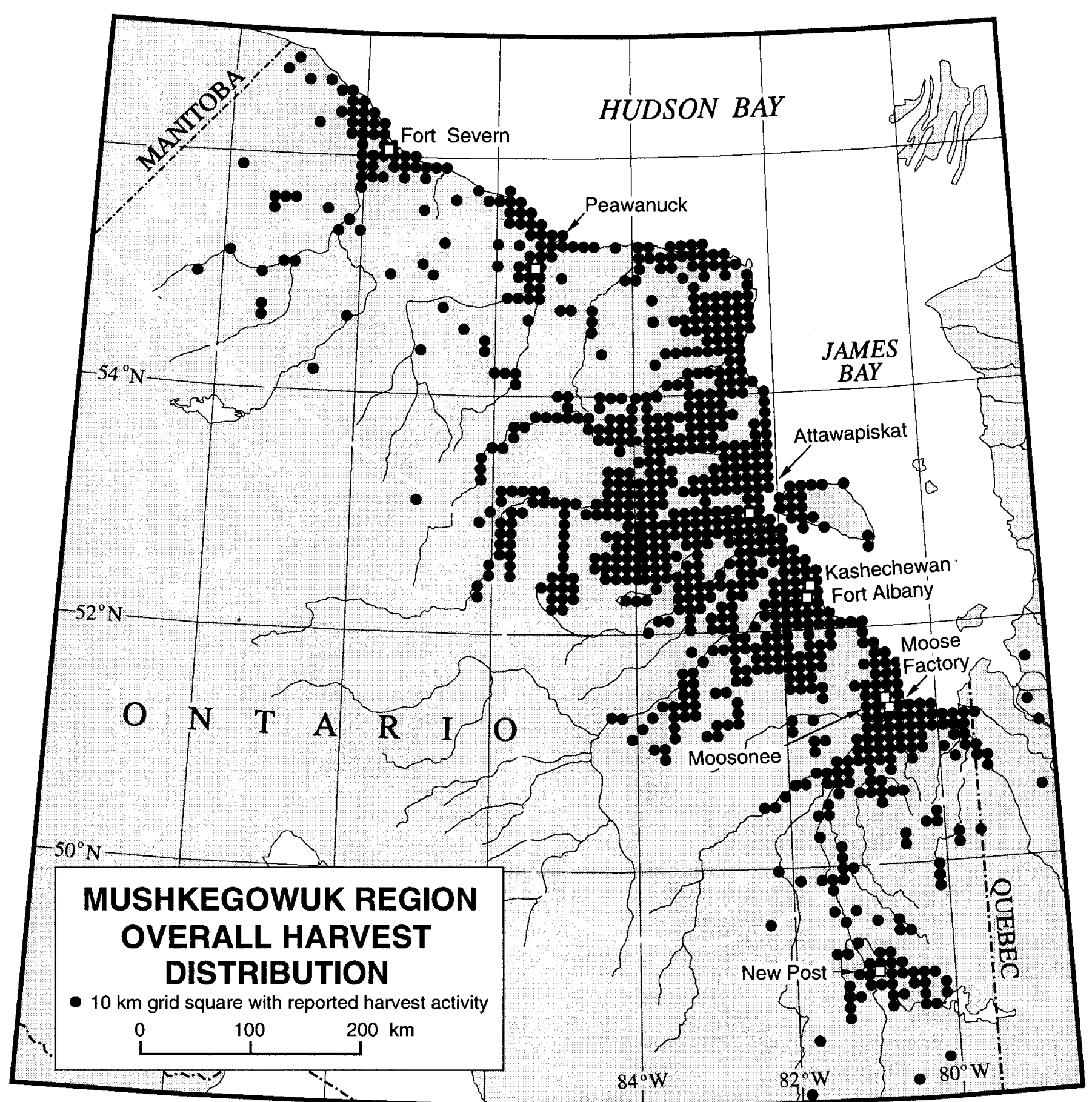

FIG. 6. Distribution of harvest activity in 1990, all major species, all seasons, all communities. The traditional territory of the Omushkego (West Main) Cree is indicated by the dashed line; it is an approximation only and not based on specific historical land occupancy and use information (Honigmann, 1981; George and Preston, 1987).

great deal over the last few decades. The Omushkego Cree used to live on the land in scattered hunting groups for some 89 months of the year and get together only in summer in trading post communities (Preston, 1986); instead, the Omushkego Cree of 1990 carry out much of their harvesting on shorter trips from permanent communities, relying on modern transportation technology. As Table 3 shows, only two communities (Moose Factory and Kashechewan) had any significant number of trappers who stayed in the bush for over a month. Hunters targeting waterfowl and big game were likely to stay in camp for shorter periods than trappers. The highly productive harvests in Fort Severn, Peawanuck, and New Post, all small communities, were carried out largely on trips of a few days' duration.

This contemporary hunting pattern is the outcome of a policy of settling indigenous populations into centralized communities, a policy motivated by the belief that a landbased economy was not viable, and that indigenous peoples should be integrated into the modern wage economy. But wage 
opportunities were scarce, and large development projects were not significant providers of jobs for aboriginal people (e.g., Salisbury, 1986; George et al., in press). Located far from game, people were able to provide for themselves only by channelling cash from transfer payments and wage employment into mechanized, rapid transportation for access to traditional resources.

The ability of the Omushkego Cree to continue the extensive use of the land made it possible for them to harvest about $400 \mathrm{~g}$ of wild meat (or $97 \mathrm{~g}$ protein) per adult-equivalent per day in 1990 (Berkes et al., 1994). Regionally, the value of the land-based economy was some $\$ 9.4$ million worth of meat and other land-based products, or about $\$ 8400$ per household in 1990. However, extensive land use and harvesting activity were made possible only by an estimated $\$ 25500$ per year of cash income per household, emphasizing the importance of a mixed economy in which cash income and self-reliance become mutually supporting (Berkes et al., 1994).

Considering the continued importance of land-based activities, the First Nations desire a more active role in resource management in the region; this is recognized to some extent by governments (Moose River Basin Project, 1994). As the results of the present project indicate, almost all of the harvests come from Crown lands over which First Nations have no recognized jurisdiction.

The traditional territory of the Omushkegowuk people and the outer boundary of harvest locations in 1990 (Fig. 6) enclose an area of about $250000 \mathrm{~km}^{2}$. The magnitude of land use that is represented in Figure 6 is based on a one-year snapshot of harvest locations; it no doubt is only a part of the land actually used. Within this area, about $900 \mathrm{~km}^{2}$ is Indian Reserve land (OMNR, 1985). Thus, the First Nations control only about $0.36 \%$ and yet continue to use most of their traditional land.

The regional land-based economy is vulnerable to industrial development such as hydroelectric projects, mining, and forestry, and First Nations have little opportunity to control such development or protect the land resource base. Yet it is well known in the common-property literature that communities that depend on local resources have a higher success rate in sustainable resource use than developers from the outside who have the option of moving on to other resource areas or converting their investments (e.g., Brody, 1981; Usher, 1987; Berkes et al., 1991). The presence of social constraints and collective community interest help avoid the pitfalls of the "tragedy of the commons," provided that social institutions regulating communal resource use remain healthy (Berkes, 1989).

The planners of the development decade of the 1970s, along with many Canadians looking at "empty" maps of the North, assumed the North was very largely free of human use. The scepticism that met some of the early studies of aboriginal land use has given way to a major change in the perception of the North by the South. Aboriginal land use and land-based economies persist, and do not seem to be disappearing, for the simple reason that the major produce of the land is wildlife, which continues to be a mainstay. It makes sense to use this renewable resource as the basis of an environmentally and culturally sustainable economy.
Land use studies have implications for sustainable development planning, for Native land claims, and for the empowerment of local populations, not only in the North but also elsewhere (Aberley, 1993; Weinstein, 1993; Denniston, 1994). Such studies help provide the information base needed to work effectively toward the self-governance of First Nations and the co-management of resources important for all.

\section{ACKNOWLEDGEMENTS}

We thank M. Anderson (Manitoba Keewatinowi Okimakanak), H. Fast (University of Manitoba) and M. Weinstein (Comox, BC) for comments and assistance. We gratefully acknowledge the cooperation of the First Nations of the Mushkegowuk Council and the Omushkegowuk Harvesters Association. We thank L. Bird, C. Matthews, M. Solomon, G. Sutherland, M. Sutherland, R. Turtle and P. Wesley for administering the interviews; and J. Chernishenko, D. Flack and M. McDermott for mapping and data analysis. The project was supported by the Social Sciences and Humanities Research Council of Canada (SSHRC) research grant to Preston, George and Berkes, the principal investigators of TASO.

\section{REFERENCES}

ABEL, K., and FRIESEN, J., eds. 1991. Aboriginal resource use in Canada: Historical and legal aspects. Winnipeg: University of Manitoba Press.

ABERLEY, D., ed. 1993. Boundaries of home: Mapping for local empowerment. Gabriola Island, British Columbia: New Society Publishers.

ANDREWS, E.F. 1994. Territoriality and land use among the Akulmiut of Western Alaska. In: Burch, E.S., Jr., and Ellanna, L.J., eds. Key issues in hunter-gatherer research. Oxford: Berg. 65-93.

ASCH, M., and TYCHON, G.G. 1993. The Dene Mapping Project: Past and present. Proceedings of the 7th Annual Symposium on GIS in Forestry, Environment and Natural Resources Management. Vancouver: GIS '93 Symposium. 731-734.

BERKES, F., ed. 1989. Common property resources. London: Belhaven.

BERKES, F., GEORGE, P., and PRESTON, R.J. 1991. Comanagement. Alternatives 18(2):12-18.

BERKES, F., GEORGE, P., PRESTON, R., TURNER, J., HUGHES, A., CUMMINS, B., and HAUGH, A. 1992. Wildlife harvests in the Mushkegowuk region. TASO Report, Second Series, No. 6. 68 p. Available from TASO, McMaster University, Hamilton, Ontario L8S 4M4, Canada.

BERKES, F., GEORGE, P.J., PRESTON, R.J., HUGHES, A., TURNER, J., and CUMMINS, B.D. 1994. Wildlife harvesting and sustainable regional native economy in the Hudson and James Bay Lowland, Ontario. Arctic 47(4):350-360.

BRICE-BENNETT, C., ed. 1977. Our footprints are everywhere. Nain, Newfoundland: Labrador Inuit Association. 380 p.

BRODY, H. 1981. Maps and dreams. Vancouver: Douglas and McIntyre. 
CUMMINS, B.D. 1992. Attawapiskat Cree Land Tenure and Use. Ph.D. Thesis, McMaster University, Hamilton, Ontario.

DENNISTON, D. 1994. Defending the land with maps. World Watch 7(1):27-31.

FAST, H., and BERKES, F. 1994. Native land use, traditional knowledge and the subsistence economy in the Hudson Bay bioregion. Ottawa: Canadian Arctic Resources Committee/ Environmental Committee, Municipality of Sanikiluaq/Rawson Academy of Aquatic Science. 33 p. Available from CARC, 1 Nicholas Street, Suite 412, Ottawa K1N 7B7, Canada.

FEIT, H.A. 1991. Gifts of the land: Hunting territories, guaranteed incomes and the construction of social relations in James Bay Cree society. Senri Ethnological Studies 30:223-268.

FLANNERY, R., and CHAMBERS, M.E. 1986. John M. Cooper's investigation of James Bay family hunting grounds, 1927-1934. Anthropologica NS 28:108-144.

FREEMAN, M.M.R., ed. 1976. Report of the Inuit land use and occupancy project. 3 vols. Ottawa: Department of Indian and Northern Affairs.

GEORGE., P. 1989. Native peoples and community economic development in northern Ontario. British Journal of Canadian Studies 4:58-73.

GEORGE, P., and PRESTON, R.J. 1987. "Going in between": The impact of European technology on the work patterns of the West Main Cree of northern Ontario. Journal of Economic History 47:447-460.

GEORGE, P., and PRESTON, R.J. 1992. The TASO research program: Retrospect and prospect. Anthropologica 34:51-70.

GEORGE, P., BERKES, F., and PRESTON, R.J. In press. Aboriginal harvesting in the Moose River basin: A historical and contemporary analysis. Canadian Review of Sociology and Anthropology.

HALLOWELL, A.I. 1992. The Ojibwa of Berens River, Manitoba: Ethnography into history. Brown, J.S.H., ed. Toronto: Harcourt, Brace, Jovanovich.

HONIGMANN, J.J. 1961. Foodways in a muskeg community. An anthropological report on the Attawapiskat Indians. Ottawa: Department of Northern Affairs and Natural Resources. 214 p. . 1981. West Main Cree. In: Helm, J., ed. Subarctic, Handbook of North American Indians, vol. 6. Washington, D.C.: Smithsonian Institution. 217-230.

HRENCHUK, C. 1993. Native land use and common property: Whose common? In: Inglis, J.T., ed. Traditional ecological knowledge: Concepts and cases. Ottawa: Canadian Museum of Nature/International Development Research Centre. 69-86.

HUGHES, A., BERKES, F., GEORGE, P., PRESTON, R., TURNER, J., CHERNISHENKO, J., and CUMMINS, B. 1993. Mapping wildlife harvest areas in the Mushkegowuk region. TASO Report, Second Series, No. 10.33 p.+43 maps. Available from TASO, McMaster University, Hamilton, Ontario L8S 4M4, Canada.
KAYAHNA TRIBAL AREA COUNCIL. 1985. The Kayahna Region land utilization and occupancy study. Toronto: University of Toronto Press, and Kayahna Tribal Area Council.

MOOSE RIVER BASIN PROJECT. 1994. A proposal for an environmental information partnership in the Moose River Basin. Timmins: Ontario Ministry of Natural Resources.

NATIVE HARVESTING RESEARCH (NHR). 1982. The wealth of the land. Wildlife harvests by the James Bay Cree 1972-73 to 1978-79. Quebec: James Bay and Northern Quebec Native Harvesting Research Committee. 811 p.

NIEZEN, R. 1993. Power and dignity: The social consequences of hydro-electric development for the James Bay Cree. Canadian Review of Sociology and Anthropology 30:510-529.

ONTARIO MINISTRY OF NATURAL RESOURCES (OMNR). 1985. Moosonee District background information. Toronto: OMNR. 167 p.

PRESTON, R.J. 1986. Twentieth century transformations of the west coast Cree. Actes du Dix-Septieme Congres des Algonquinistes. 239-251.

PREVETT, J.P., LUMSDEN, H.G., and JOHNSON, F.C. 1983. Waterfowl kill by Cree hunters of the Hudson Bay Lowland, Ontario. Arctic 36:185-192.

RIDINGTON, R. 1988. Trail to heaven. Vancouver: Douglas and McIntyre.

RIEWE, R., ed. 1992. Nunavut atlas. Edmonton: Canadian Circumpolar Institute and the Tungavik Federation of Nunavut.

SALISBURY, R.F. 1986. A homeland for the Cree: Regional development in James Bay 1971-1981. Kingston and Montreal: McGill-Queens University Press.

SCHUURMAN, L., PRESTON, R.J., BERKES, F., and GEORGE, P. 1992. Cultural-historical reconstruction of New Post. TASO Report, Second Series, No. 7. 80 p. Available from TASO, McMaster University, Hamilton, Ontario L8S 4M4, Canada.

THOMPSON, J.E., and HUTCHISON, W.A. 1989. Resource use by native and non-native hunters of the Ontario Hudson Bay Lowland. Toronto: Ontario Ministry of Natural Resources. 150 p.

USHER, P.J. 1987. Indigenous management systems and the conservation of wildlife in the Canadian North. Alternatives 14(1):3-9.

USHER, P.J., and WENZEL, G. 1987. Native harvest surveys and statistics: A critique of their construction and use. Arctic 40: 145-160.

WEINSTEIN, M.S. 1976. What the land provides. Montreal: Grand Council of the Crees (of Quebec). 255 p. Available from Grand Council of the Crees (of Quebec), 1, Place Ville-Marie, Bureau 3438, Montreal, Quebec H3B 3N6, Canada.

WEINSTEIN, M.S. 1993. Aboriginal land use and occupancy studies in Canada. Workshop on Spatial Aspects of Social Forestry Systems, Chiang Mai University, Thailand. Available from M.S. Weinstein, 108 Croteau Road, Comox, British Columbia V9N 7X2, Canada. 